\title{
COLLATERAL ATTACK OF JUDICIALLY-APPROVED SETTLEMENTS OF SHAREHOLDERS' DERIVATIVE SUITS
}

THE seemingly endless skirmishes for control of the Alleghany Corporation have been accompanied by extensive litigation, ${ }^{1}$ culminating in a recent decision by the Second Circuit in Alleghany v. Kirby. ${ }^{2}$ This case clearly raised important questions concerning settlement of shareholders' derivative suits. But the Second Circuit failed to reach the unusual substantive issue raised, thits leaving unanswered the question of how the rights of the corporation and of absent third parties may be protected following a judicially-approved settlement of a derivative suit marked by questionable conduct on one side or the other.

The present controversy arose out of a transaction in 1951 in which the defendant Kirby, with other directors of Alleghany, participated in a plan whereby the directors' holdings of preferred stock in Alleghany were redeemed by exchanging them for shares of common stock of Investors' Diversified Services (IDS) at the then market value of IDS, $\$ 8.15$ per share. Five years later, the market price of IDS common had risen to $\$ 200.00$ a share. This enormous appreciation in the market value of IDS stock aroused suspicion among dissident shareholders, who instituted a derivative suit, $Z_{c n n}$ v. Anzalone. ${ }^{3}$ The plaintiffs alleged that the directors, because of information available only to them, had foreseen the incredible increase in the value of the IDS stock, and had therefore appropriated a corporate opportunity. The directors defended on the grounds that the exchange was reasonable because of the corporation's desire to liquidate its outstanding preferred stock, and because the increase in value of IDS was not foreseeable by them at the time of the transaction. 4 Plaintiffs made extensive discovery demands for "all forecasts or budgets concerning IDS and its subsidiaries prepared by or for the use of Alleghany or IDS and their officers and directors during the year 1949 and the first six months of 1950." Although the defendants had the crucial schedules within their possession they refused to disclose them to the sting shareholders, thereby effectively precluding the plaintiffs from proving that the increase in the IDS stock's value was foreseeable. ${ }^{\circ}$ While the case was

1. See Zenn v. Anzalone, 191 N.Y.S.2d 840 (Sup. Ct. 1959), appcal dismissed, 210 N.Y.S.2d 748 (App. Div. 1960); Breswick v. Briggs, 135 F. Supp. 397 (S.D.N.Y. 1955), noted in 65 YALE L.J. 543 (1956). See also Murchison v. Kirby, 27 F.R.D. 4 (S.D.N.Y. 1961).

2. 333 F.2d 327 (2d Cir. 1964), aff'd en banc 340 F.2d 311 (2d Cir. 1965) (4-4, 1 abstention).

3. 191 N.Y.S.2d 840 (Sup. Ct. 1959).

4. The corporation's "desire" to liquidate its outstanding preferred stock was expressed just prior to the transaction by a directors' resolution to that effect; the resolution was apparently adopted solely for the purpose of legitimizing the IDS exchange.

5. 333 F.2d at 341 .

6. Kirby was not served by the plaintiffs in Zenn since he could not be reaclied by process. However, Kirby sought to invoke the Zeinn settlement as res judicata in the present litigation, and accordingly, he had no justification for claiming that the non-dls- 
still in the early motions stages, the defendants commenced settlement overtures. The parties reached an agreement, and, pursuant to New York practice, in order to make the settlement binding on all shareholders they submitted the proposal to the court for an inquiry as to its fariness. ${ }^{7}$ The court appointed a referee, objecting shareholders were heard and afforded the benefits of discovery and inspection of the files of both the corporation and the individual defendants, and examinations of the principal witnesses were conducted. The referee was eventually persuaded of the fairness of the settlement figure.

Meanwhile, however, other shareholders pursuing a derivative suit in federal court - Breswick v. Briggs ${ }^{8}$ - based on the same cause of action and against the same defendants, had obtained from the district court an order enjoining the defendants from setting up the res judicata effect of the state court settlement decree until negotiations had been conducted with the federal court plaintiffs. Negotiations with the Breswick plaintiffs resulted in an increased offer of settlement which, although favorably received by the special master appointed by the federal court, was rejected by that court. This rejection led to still another offer which the federal court accepted, vacating the injunction. The New York Supreme Court then entered an order approving the settlement, as augmented by the federal court proceedings. ${ }^{8}$

In the present action, a third group of shareholders sought to attack collaterally in federal court the New York court's order on the ground that the defendants in the earlier suit had failed to adduce before the referee and the state court facts and documents which would have shown that the directors, at the time of the IDS exchange, were fully aware of the probability of staggering price appreciation in the shares they acquired. ${ }^{10}$ The district court

closures of his cohorts in Zenn should not be used to defeat his defense of res judienta. Judge Moore seems to suggest at several places that Kirby should not be blamed for the conduct of his accomplices, apparently forgetting that it is Kirby who seclis to protect himself from liability by introducing the $Z$ enn settlement.

Further, Judge Moore apparently feels that the Kirby plaintiffs had not shown that the evidence claimed to have been withheld was available to the $Z$ enn defendants or in the Alleghany files at the time its disclosure was sought. Judge Mfoore is most likely in error on this point. A letter from Young to Purcell at a time when the latter was negotiating for settlement with the Zenrs plaintiffs clearly demonstrates that both men must have been aware of the evidence and its devastating potentiality. 333 F.2d at 339 .

7. At the time of the $Z$ enns settlement the requirement of court approval vas of common law origin. See generally Gerith Realty Corp. v. Normandie Nat'l Securities Corp., 276 N.Y.S. 655 (1933), affd, 266 N.Y. 525, 195 N.E. 183 (1935). Now, however, the requirements have a statutory basis, although the Gerit/s decision provides the procedural means for carrying out the statutory mandate. See N.Y. CPLR § 1005.

8. 135 F. Supp. 397 (S.D.N.Y. 1955). See generally Note, 65 Y ALE L.J. 543 (1956).

9. Zenn v. Anzalone, 191 N.Y.S.2d 840 (Sup. Ct. 1959), appeal dismissed, 210 N.Y.S. 2d 748 (App. Div. 1960).

10. Although Judge Moore's.opinion casts aspersions on the probative value of the undisclosed evidence, it is assumed for purposes of this Note that the evidence proffered was sufficient to demonstrate the foreseeability of the IDS price increase. Further, cven if the evidence was not materially sufficient to justify a new trial, the Second Circuit had no business undertaking an independent factual review of the evidence. The proper procedure, if the Second Circuit was unsure of the materiality of the withheld information would 
held that the defendants' failure to disclose the prejudicial documents did not constitute an "extrinsic" fraud. The court found that the directors' conduct constituted merely an "intrinsic" fraud, which by application of settled doctrine would not be subject to a collateral attack. ${ }^{11}$ Surprisingly, in reaching this conclusion the district court failed to mention the fact that there had been specific discovery demands made during the course of the $Z_{c n n}$ proceedings requesting the evidence which was withheld. ${ }^{12}$ On appeal, Judge Moore, writing for the majority, concentrated on the issue of the materiality of the undisclosed evidence and concluded that it was not of sufficient weight to justify collateral attack. Judge Moore expressly stated that in view of the failure of the plaintiff to overcome the hurdle of materiality - a traditional precondition to collateral attack - no examination of the district court's holding that the directors' conduct was merely an intrinsic fraud would be necessary. ${ }^{13}$ Because the Second Circuit failed to reach the extrinsic-intrinsic fratud issue, the district court's interpretation of the extrinsic-intrinsic fraud rule was left intact. This interpretation, if followed, will have grave consequences for the efficacy of the shareholders' derivative suit as a mechanism of corporate control. The result reached by the district court not only encourages strike suits, but does not sufficiently protect the interests of non-represented shareholders.

The district court's distinction between extrinsic and intrinsic fratd collateral attack of a firial judgment being permitted only in the event of the former - is one sanctioned by the majority of American jurisdictions. ${ }^{14}$ The have been to remand to the district court for a clarification of that court's findings on the issue.

11. 218 F. Supp. 164, 182-85 (S.D.N.Y. 1963).

12. See note 5 supra.

13. 333 F.2d at 336.

14. Note, 22 HARv. L. REv. 600 (1909).

As to what constitutes such fraud as to justify equitable interference the authorities are in conflict. The great majority, however, require that the fraud shall be extrinsic and collateral and not relative to an issue tried in the court of law. Id. at 601 .

For an example of the minority rule adhered to by Wisconsin, which allows collateral attack for intrinsic frauds, such as perjury, see Laun v. Kipp, 155 Wis. 347, 145 N.W. 183 (1914) ; Boring v. Ott, 138 Wis. 260, 119 N.W. 865 (1909).

The real principal of the adjudications [in Wisconsin] is that the power of equity to relieve against unconscionable judgments will not be strictly confined to such as are characterized by fraud extrinsic....

[T] he vital question to be determined in such a case as this, is not, merely, whether the judgment was secured by fraud, extrinsic, without inexcusable fault of the aggrieved party, but was it secured by fraud without such fault, and are the circumstances so serious that the doors of equity ought not to open to afford relief? Laun v. Kipp, 155 Wis. 347, 372, 145 N.W. 183, 192 (1914).

The doctrine of Laun v. Kipp is accepted in Wisconsin today, the courts holding that collateral attack is one of the general equity powers of the court, and hence that it should be available at the court's discretion. Weber v. Weber, 260 Wis, 420, 51 N.W.2d 18 (1952).

Although modern procedural statutes have adopted the liberality of the minority rulo permitting relief from intrinsic frauds, this remedy is available for only a limited period 
United States Supreme Court initially laid down the rule that judgments could be attacked collaterally only for extrinsic fraud in United States $v$. Throckmorton. ${ }^{15}$ The Throckmorton formulation has since become the classic statement of the doctrine:

relief has been granted, on the ground that by some fraud practiced directly upon the party seeking relief against the judgment or decree, that party has been prevented from presenting all of his case to the court.

On the other hand, the doctrine is equally well settled that the court will not set aside a judgment because it was founded on a fraudulent instrument, or perjured evidence, or for any matter which was actually presented and considered in the judgment assailed. ${ }^{10}$

of time, customarily one year. See, e.g., FED. R. Crv. P. 60 (b) (3). After one year has passed an aggrieved party must rely on the general equity powers of the court, and must show that he has been victimized by an extrinsic fraud, and that he is not guilty of laches.

15. 98 U.S. 61 (1878). There is some justification for contending that the rule hid down by Throcknorton is not good law today in the light of the Supreme Court's decision thirteen years later in Miarshall v. Holmes, 141 U.S. 589 (1891). In Mfarshall the court afforded the complainant relief from a judgment because of the successful party's introduction of a forged document in the original action (typically an intrinsic fraud). The court laid down the rule that collateral attack should be permitted whenever it should be proved "to be against conscience to execute a judgment," seemingly placing collateral attack within the discretion of the court in a manner similar to the Wisconsin cases cited in note 14 sipra. 141 U.S. 589 at 596 (1891).

Although most commentators assume that the rule of Throckmorton is the valid one, and most cases follow the doctrine laid down therein, there is still room for considerable uncertainty as to the status of the rule. In 1896 the Supreme Court ignored an opportunity to remove the confusion by denying certiorari in Graver v. Faurot, 162 U.S. 435 (1896). The reaction of the commentator in Note, 21 CoLuxr. L. REv. 268 (1921) is not atypical:

The Supreme Court of the United States to show its utter impartiality, has ruled both ways, and left the spectacle of two cases, one of which holds that false evidence is a ground for reversal [Marshall], the other that it is not [Throckmorion], both of which have been followed, and neither of which has ever been overruled. In fact, when a Circuit Court, somewhat puzzled as to which of the two authorities it would follow, asked for enlightenment [Graver v. Faurot, 64 F.2d 241 (N.D. IIL. 1894)], the Supreme Court refused to commit itself by answering.

See also the Supreme Court's denial of certiorari in Publicker v. Shalleross, 303 U.S. 624 (1940), leaving intact the lower court's assertion that Throckmorton was no longer good law, Publicker v. Shallcross, 106 F.2d 949, 950 (3d Cir. 1939).

Despite this seeming confusion Professor Moore is convinced that Throckmorion remains the authoritative expression of the Supreme Court. 7 19oore, Federni Practice 616 (1955).

16. 98 U.S. 6166 (1878). New York has accepted the Throckmorlon formulation without reservation. See, e.g., Crouse v. AIcVickar, 207 N.Y. 213, 218, 100 N.E. 697 (1912).

For a case applying the New York law on extrinsic-intrinsic fraud to the sharcholders' derivative suit situation, see Reiter v. Universal Marion Corp, 299 F.2d 449 (D.C. Cir. 1962). In Reiter a derivative suit had been started in the district court for the District of Columbia; however, before the case came to trial, a similar suit against the same defendant had been settled in the New York Supreme Court, and judicial approval had been seeured. The plaintiffs sought to attack the New York settlement collaterally on the ground that the director-defendants had withheld information bearing upon their liability which would 
Many courts have woodenly applied the extrinsic-intrinsic fraud rule assuming a rigid dichotomy:17 any fraud, such as perjury, perpetrated within the courtroom is considered intrinsic; fraudulent conduct which meddles with the judicial machinery, such as bribing an opponent's attorney, is treated as extrinsic. The futility of seeking to apply a mechanical formulation of the extrinsic-intrinsic fraud rule is demonstrated by the celebrated case of Chicago, R.I. \& Pac. R. v. Callicotte. ${ }^{18}$ The plaintiff, injured as a result of the defendant railroad's negligence, feigned paralysis. $\mathrm{He}$ was so successful in this ruse that the defendant's own expert witnesses, misled into thinking that the plaintiff indeed was paralyzed, testified accordingly. Plaintiff's conduct consisted of perjuring himself, having perjured witnesses testify on his behalf and stbmitting fraudulent documents; all these actions are traditionally labelled intrinsic frauds. ${ }^{19}$ The court, however, held that his conduct constituted extrinsic fraud, apparently resting its holding on the assumption that the perjury so pervaded the proceeding that there was no possibility of impeaching the veracity of the plaintiff's testimony from the information available to the defendant and the court. The defendant in Callicotte was, in effect, so incapacitated by the plaintiff's conduct that he was unable to function as an adversary. The court and the jury were thus foreclosed from making an impartinl decision because their consideration of the case proceeded from the false assumption that the plaintiff was indeed paralyzed.

The fact that the extrinsic-intrinsic rule often breaks down when applied mechanically does not mean that the rule itself is unworkable or outmoded. ${ }^{20}$ The rule, as formulated in Throckmorton, strikes a balance between the competing interests of finality and justice in the individual case. The rule thus represents nothing more than a logical outgrowth of the philosophy of res judicata. Issues fully litigated in a prior suit should not be continually reopened; otherwise, there would be no protection for the successful litigant from the harrassing tactics of a disgruntled opponent. In the classic example of an intrinsic fraud - perjury - the determination of the trier of fact, either

have increased the figure of settlement. The district court felt bound to apply New York substantive law and dismissed the suit. The Court of Appeals affirmed:

[W] are bound by New York law on the matter, and it seems clear that the New York courts would not permit a collateral attack upon a settlement and resulting judgment on the basis appellants urge.

299 F.2d 449 at 453.

17. See Bolden v. Sloss-Sheffield Steel \& Iron Co., 215 Ala. 334, 110 So. 574 (1925).

18. 267 F. 799 (8th Cir. 1920), cert. denied, 255 U.S. 570 (1921).

19. See Note, 22 Harv. L. Rev. 600 (1909). See also Josserand v. Taylor, 159 F.2d 249 (C.C. $\mathrm{Pa}$. 1946).

20. Critics of the extrinsic-intrinsic fraud rule often seize upon the result in Callicolle and similar cases to point out that the rule is unworkable because, if strictly followed, cases like Callicotte are wrongly decided. See, e.g., 7 Moore, Federal Practrce 613-14 (1955). The rule requires a flexible application which avoids ironclad categorization of actions as intrinsic or extrinsic and a realization that perjury may consistently be labeled extrinsic or intrinsic depending upon the effect of the perjury upon the adversary process which may be dehabilitating as in Callicotte, and therefore requiring relief. 
judge or jury, disposes of the question of credibility. To say that the judgment should be reopened because one of the witnesses perjured himself is merely to fault the tribunal's determination on the issue of the witness' credibility. A different court should not be allowed to reexamine the original determination unless the circumstances surrounding the commission of the perjury are extraordinary. ${ }^{21}$ Res judicata principles, however, proceed from the assumption that there has been an adversary determination of the issues. Accordingly, when the conduct of one party precludes adversary determination of an issue by emasculation of the litigative machinery, it becomes inequitable and impolitic to insist on the policy of finality. In Callicotte, for example, because the plaintiff's conduct effectively disarmed the adversary process, the vital issue of the actual extent of the plaintiff's injuries was never joined. It was precisely to avoid the res judicata effect of such non-adversary determinations that courts constructed the extrinsic fraud rule which permits the injured party to attack collaterally judgments rendered without an effective trial on the relevant issues.

Thus, the proper concern of courts administering the extrinsic-intrinsic fraud rule should be the adversary nature of the original proceedings and the question whether the actual issues were litigated. Viewing the extrinsic fraud rule in this light the decision in Callicotte ceases to be merely a case demonstrating the difficulties involved in a mechanistic interpretation of the rule and stands as a clear example of how the rule should be applied. Recent procedural statutes ${ }^{22}$ further demonstrate the desirability of avoiding a mechanical application of the extrinsic-intrinsic dichotomy. Instead these statutes demand exploration of the equities of the individual case and suggest investigation of whether there has been a truly adversary proceeding.

Yet another and stronger indication that an enlightened application of the extrinsic-intrinsic fraud rule should concern itself with the adversary nature of the proceedings is contained in two lines of cases, commonly called exceptions to the rule, but in reality nothing more than logical corollaries of its underlying policy. The first "exception" involves collateral attack on arbitration awards. Courts, although unwilling to relieve litigants from perjury and other intrinsic frauds perpetrated in the course of trial, have often demonstrated their willingness to relieve parties from similar conduct occurring during arbitration proceedings, even where the arbitration has received the imprimatur of a court. ${ }^{23}$ The rationale is that the arbitral arena lacks

21. See, e.g., Chicago, R.I. \& Pac. Ry. v. Callicotte, 267 F. 799 (8th Cir. 1920), cert. denied, 255 U.S. 570 (1921).

22. See, e.g., FED. R. CIv. P. 60(b) (3). See also N.Y. CPLR § 5015(a) (3). Unfortunately the protection of the federal rule is only available if invoked within one year; following the year period the injured party must rely on the Throckmorton rule. There is no such limitation on the discretionary powers of the New York courts. Further, both rules are directed toward efforts to secure relief from judgments by motion in the court which rendered the judgment; there is no alteration fo the extrinsic-intrinsic dichotomy required for an independent action.

23. Johnson v. Wells, 72 Fla 290, 73 So. 188 (1916); Chambers v. Crook, 42 Ala. 171 (1868). Costra, French v. Raymond, 82 Vt. 152, 72 Att. 324 (1909). 
many of the time-honored procedural and substantive safeguards of the juk dicial process, ${ }^{24}$ and it is more likely that perjury and other intrinsic frauds may be successfully perpetrated in the absence of traditional adversary machinery. In the light of this increased probability of undetected fratt, courts feel that finality should not be allowed to outweigh automatically the policy of justice in the individual case.

Similarly, the underlying rationale of the extrinsic-intrinsic fratd rule is demonstrated in a line of cases commonly called the "fiduciary exception" to the rule. ${ }^{25}$ An illustrative case in this area is In re Enger ${ }^{20}$ where the trustees, pursuant to court order, had made dispositions of trust property which resulted in losses to the trust and gains to the individual trustees who, unknown to the court, were interested in the court-approved transactions as purchasers. The trustees had also, pursuant to a second court order, transferred assets of a corporation controlled by the trust to a new corporation controlled by the trustees in return for which the trust received stock in the new corporation. Subsequently, the trustees, as directors of the new corporation, diverted the corporate earnings to themselves by way of salaries and bonuses, leaving insufficient funds available for dividends. The beneficiaries, after ascertaining the realities of the transactions involved, brought stit against the trustees who, introducing the court orders, claimed the protection of res judicata. The court permitted the beneficiaries to proceed against the trustees, vacating the complained-of orders. The court found that there was a fiduciary duty running from the trustees to the beneficiaries ${ }^{27}$ which entitled the beneficiaries to rely on the veracity of the trustees' disclosures..$^{28}$ The court pointed out that because of the fiduciary relationship between the parties, and because the actual nature of the transactions approved by the court had not been disclosed, the authorization proceedings could not be characterized as truly adversary. This case and others like it are often cited for the proposition that where there is a fiduciary duty owing between the parties, the breach of that duty will constitute an extrinsic fraud. A more appropriate reading of these cases, however, is that because the fiduciary relationship entitles the

24. There are many examples of the procedural informalities of arbitration proccedings. Lumbard v. Holdiman, 115 Ill. App. 458 (1904) (legal incompetency of witncsses); Pennsylvania Iron Works Co. v. East St. Louis Ice and Cold Storage Co., 96 Mo. App. 563, 70 S.W. 903 (1902) (no cross-examination by trained counsel); In re Schwartz, 217 N.Y.S. 233 (1925) (preliminary examination denied); Smyth v. Board of Education, 217 N.Y.S. 231 (1925) (application for a bill of particulars denied); A. O. Anderson Trading Co. v. Brimberg, 197 N.Y.S. 289 (1922) (hearsay evidence admitted).

25. Some examples of this "exception" are: Fiske v. Buder, 125 F.2d 841 (8th Cir. 1942); Park v. Park, 123 F.2d 370 (5th Cir. 1941); Pickens v. Merriam, 242 F. 363 (9th Cir. 1917); Lataillade v. Orena, 91 Cal. 565, 27 Pac. 924 (1891); Pico v. Cohn, 91 Cal. 129, 25 Pac. 970 (1891).

26. 225 Minn. 229, 30 N.W.2d 694 (1948).

27. "The duty of disclosure does not end at the commencement of a legal procecding, but continues to be just as obligatory therein as it was prior thereto." Id. at 239.

28. Id. at 240 . 
beneficiary to rely on the fiduciary's disclosures there has been no adversary contest of the issues involved $;^{29}$ since there has been no adversary proceeding the policy of res judicata becomes inappropriate.

The shareholders' derivative suit and its ancillary settlement proceedings, like arbitration cases and fiduciary cases, represent areas where actual adversity is often lacking. In many derivative suits the substantive, ${ }^{30}$ procedural ${ }^{31}$ and practical ${ }^{32}$ difficulties facing the derivative plaintiffs are so tremendous that he is often effectively precluded from ever litigating the issues in court. In the event the plaintiff is able to bring the case to trial, he is frequently incapable of effectively prosecuting the cause of action. The shareholder vishing to sue must first secure competent counsel and make provision for his ex'penses and fees. ${ }^{33}$ In many commercial states the plaintiff must also post

29. In other words the fiduciary's breach of his duty to disclose the intriacies of the transaction to the court and the beneficiary is an affront to the integrity of the judicial process. In the area of authorization proceedings the court is forced to rely upon the trustees' disclosures - tuless the trustee reciprocates this trust by disclosing accurate information the authorization proceeding is incapable of functioning properly. It is the trustce's misconduct which has incapacitated the machinery. Accordingly, his breach of his duty to disclose is an extrinsic fraud because of its nefarious effect on the judicial proceedings.

30. The substantive difficulties stem from the difficulty of proving such nebulous charges as "mismanagement" where the director may always plead that his actions wert but a legitimate exercise of managerial discretion. Similarly, in actions like Kirby the defense of unforeseeability may prove to be an unpenetrable armor because of the dificulty of obtaining proof on this vital element. As long as the transaction was not patently fraudulent the defendant's claims of "within the scope of discretion" and "reasonable" behavior will absolve the director from liability for what with the advantage of hindsight will appear to be atrocious business judgment. Cf. Purdy v. Lynch, 145 N.Y. 462, 475, 40 N.E. 232, 236 (1895).

31. Since the corporation is an indispensable party both the corporation and the directors must be served; hence, they must both be found in the same jurisdiction. Some jurisdictions have made an effort to cope with this impasse, as, for example, Delaware which allows the court to seize the directors' property in order to coerce an appearance. $10 \mathrm{DEL}$ Stat. § 366. See also Pomeroy v. Simon, 17 N.J. 59, 110 A.2d 19 (1954). In Michigan, non-resident directors must appoint the company's resident agent as their attorney for scrvice of process.

Federal diversity jurisdiction may be invoked only if there is complete diversity between the plaintiffs and the defendants. Strawbridge v. Curtiss, 7 U.S. (3 Cranch) 267 (1806). Naturally this is subject to the federal courts' authority to realign the partics in accordance with their real interest. For a case involving such a realignment, see Smith v. Sperling, 354 U.S. 91 (1957).

Congress has conveniently relaxed normal venue requirements found in 28 U.S.C. $\S 1391$ (a) for derivative suits by allowing suit in any district where the corporation might have sued the same defendants. 28 U.S.C. § 1401 (1948). Also service may be had on the corporation where it is organized, licensed to do or is doing business. 28 U.S.C. $\$ 1695$ (1948).

32. For a discussion of the practical difficulties, see notes 33-38 infra and accompanying text.

33. Attorneys' fees as high as $20 \%$ are not at all uncommon. See Murphy v. North American Light \& Power Co., 33 F. Supp. 567, 571 (S.D.N.Y. 1940) (allowing $\$ 200,000$ in fees out of $\$ 900,000$ recovery). Some courts go so far as to assert that without sizcable attorneys' fees there is no likelihood that the corporation will be protected from the defal- 
security for expenses, ${ }^{34}$ another substantial out-of-pocket expense. Another problem is presented by the need of the shareholder to rely on his inspection rights ${ }^{35}$ and discovery procedures to uncover facts. Although the scope of discovery is admittedly broad, in the corporate context the defendant may use the discovery procedure as a ruse or dilatory tactic. The defendant, in his selection of the files to be made available to the plaintiff, may so structure the plaintiff's evidence as to preclude the possibility of success altogether; or he may elect to obfuscate the issues behind a morass of irrelevant information. Because the corporate treasury may stand behind the defendant throughout the proceedings, he is more inclined to employ costly delaying tactics and less inclined to skimp on his defense. ${ }^{86}$ Throughout these proceedings, moreover, the plaintiff may be subject to having his cause of action foreclosed by a collusive settlement entered into by the parties to another derivative suit..$^{37}$

cations of its officials. Cf. Smolowe v. Delendo Corp., 136 F.2d 231 (2d Cir.), cert. denicd, 320 U.S. 751 (1943).

34. Examples of this type of legislation designed to counter the abuses of the strilio suit are: New York General Corp. Law \$ 61-b; Calif. Corp. Code $\S 834$. Some states waive the requirement in the event the plaintiff owns a substantial percentage of stock. ManYland Rules of Procedure 328 (5\%); Pennsylvania, Purd. Stat. ANN. title 12 , 1322 ( $5 \%$ or more at court's discretion).

35. The common law recognizes the shareholder's general right to inspect the stockholders' list and corporate books and records. See, e.g., Gavin v. Purdy, 335 Mass. 236, 139 N.E.2d 397 (1957). The shareholder seeking inspection privileges must allege and prove proper purpose. Albee v. Lamson \& Hubbard Corp., 320 Mass. 421, 69 N.E.2d 811 (1946). However, the seemingly blanket right of inspection is limited by the expenditures of both time and funds concomitant to any exercise of that right. The control group, furthermore, is not likely to have entered incriminating evidence on the corporate books or official records. The bylaws may contain reasonable restrictions on the right of inspection. These restrictions may not go so far as to give the directors complete discretion as to whether to acquiesce in a demand for inspection privileges. Klotz v. Pan-American Match Co., 221 Mass. 38, 108 N.E. 764 (1915).

Also, see generally, O'Neal, Molding the Corporate Form to Particular Business Situations: Optional Charter Clauses, 10 VAND. L. REv. 1, 30-40 (1956). O'Neal concludes that there is an important policy distinction which should be remembered concerning inspection rights between the large diffusely-held corporation and the closely-held corporation: sharehloders' inspection rights should be much more extensive in the latter since the need for shareholder initiation of controls on management is much greater.

36. See New York General Corporation Law $\S \S 63-66$, providing for indemnification of directors or officers for expenses in defending litigation if provision exists in the certificate of incorporation. Such provisions are boilerplate. The indemnification is not permissible in the event the party is found guilty of misconduct or negligence, however a settlement results in no such determination. For a cogent analysis of this particular problem see Note, 74 YaLE L.J. 524 (1965).

37. The derivative plaintiff is normally said to have the same degree of control over his suit that a plaintiff has in other types of litigation. 13 FLETCHer, Corrorutrons $§ 6019$ (perm. ed.). This right to dismiss or settle is not so absolute as it might seem at first glance. Most states now require that there be court approval of such settlements. Even in those states requiring court approval, the dissenting shareholders whose derivative suit is being foreclosed by the settlement under consideration are relegated to the status of the objectors in Kirby; not a very comforting prospect. If they should be unable to prove fraud 
Finally, the plaintiff's interest in the recovery is speculative and highly contingent; the amount is uncertain and the proceeds, after reasonable attorneys' fees, go to the corporation, so that the plaintiff must await price appreciation or dividend.declaration to realize anything on his success. This lack of an immediate financial interest ${ }^{38}$ may affect the diligence with which the plaintiff prosecutes the-suit. In sum, the pro-defendant orientation of derivative suit litigation makes the derivative arena one in which there is less likely to be a truly adversary contest on the controverted issues than in the normal litigation context. Accordingly the derivative suit should be viewed as analogous to the arbitration and fiduciary "exceptions" 39 to the extrinsic fraud rule.

This danger of a lack of adversity. is heightened in settlement proceedings ancillary to derivative-litigation. Once the parties to a derivative action have agreed on a settlement figure, they: must, in most states submit the action to the court for approval in order to bind all members of the class. In addition, some jurisdictions require that notice be sent to all members of the class affording them an opportunity to come in and be heard. ${ }^{10}$ Despite these seemingly liberal, shareholder-oriented provisions, settlement hearings are often not truly adverse. Once the suing shareholder and the defendant have come to an agreement, their interests have coalesced to the point that there is no reason to expect them to be antagonistic. Both parties will usually be most anxious to defend their agreement and to secure the finality of court approval. The suing shareholder's attorney, by securing what he deems a favorable settlement, has assured himself of a substantial contingent fee, 11 and the plaintiffshareholders, having reached a compromise will likely be unvilling to incur the additional expenses associated with protracted litigation of the issues. If the settlement figure is not approved by the court ${ }_{2}$ moreover, other members of the class may be substituted as parties plaintiff. ${ }^{2}$ Were the court to order substitution of parties, the shareholder and his attorney would lose not only the emotional security of having. agreed to a settlement, but also control of

or collusion, which are characteristically difficult of proof, there is no reason to suspect that the court would pay much attention to their anguished protestations.

38. Naturally, if the plaintiff-shareholder is his own attorney, the contingent fee provides a very substantial incentive. See Smolowe \& Delendo Corp., 136 F.2d 231 (2d Cir.), cert. denied, 320 U.S. 751 (1243). ...

39. See text at notes 23-29 supra.

40. See, e.g., N.Y. CPLR $\$ 1005$ (b). The parallel provision in the Federal Rules of Civil Procediure requires: that the court send out notice to all shareholders of the proposed compromise and afford them an opportunity to object. FED. R. Crv. P. 23(c). New York statutory-requirements are not so stringent, but there is a common law history of sending notice to shareholders of all proposed settlements which is usually followed. See Gerith Realty Corp. v. Normandie Nat'l Securities Corp., 276 N.Y.S. 655 (1933), aff'd, 266 N.Y. 525,195 N.E. 183 (1935).

41: :See note-33 supra.: · -

42. "[A]\# intervenor may have the conduct of the cause committed to him when the court finds that the action is not being prosecuted with vigor and reasonable capacity." White v. British Type Investors, 130 N.J. Eq. 157, 162, 21 A.2d 681, 684 (1941). 
the cause of action and with it most hope of receiving either a contingent fee or reimbursement for expenses incurred in prosecuting the claim.

Nor can objecting shareholders or the court be relied upon to supply the adversity necessary to test the fairness of the settlement. At the time the bargain is struck between the suing shareholder and the defendant they possess a monopoly of the relevant information, and an understanding of the intricacies of the underlying transaction not available to the court and the objecting shareholders. Although the other members of the class, if noticed, have an opportunity to employ the full panoply of discovery machinery, their ignorance of the underlying transaction and all its ramifications will probably hamper efficient employment of these devices. Finally, the defendant and the suing shareholder are benefited by the procedural rule of settlement hearings which casts a heavy burden of proof on those who would upset the settlement. All the proponents of a settlement need do to secure court approval is meet the threshold burden of establishing the fairness of the settlement figure ${ }^{18}$ not a difficult undertaking in view of the court's relative ignorance as to the full ramifications of the transaction sued upon. Once the threshold burden has been satisfied the onus devolves upon the objectors whose informational resources are likely to be inadequate to the task. If, as is more often the case, there are no objectors to the proposed settlement, the court may have no alternative but to approve the proposed figure. The court is not equipped to make an independent evaluation of the value of the cause of action, but must usually depend upon the structured evidence presented by the proponents of the settlement.

Realizing that the adversary process is more likely to breal down in the derivative suit and associated settlement proceedings, the courts, when asked to permit a collateral attack, should be flexible in their application of the extrinsic-intrinsic fraud rule. A judge, in considering the nature of the misconduct complained of in the original proceeding, should bear in mind the precarious position of the adversary process in this type of litigation, and should allow collateral attack in the event of any misconduct which threatens the minimal safeguard adversity provides in this area. In essence the courts must be very painstaking in their examination of derivative suits and settlement proceedings in order to determine whether the relevant issues were effectively litigated.

Viewed in this light, Kirby is indeed an easy case, and there is no question but that the district court completely missed the crucial element in the case. As Judge Friendly carefully noted in his dissent on appeal, the defendants in the Zenn action were presented with specific discovery demands requesting

43. Courts are generally required to ascertain whether the amount offered in compromise is fair given the "probability" of success. See Zenn v. Anzalone, 191 N.Y.S.2d 840 (Sup. Ct. 1959), appeal dismissed, 210 N.Y.S.2d 748 (1960). To determine fairness the proponents must show that the amount offered covers all the elements of the plaintiff's claim. Naturally the proponents may so structure the evidence as to make the court believe that the plaintiff's claim would not be likely to succeed. 
all information relevant to the IDS earnings picture at the time of the 1950 transaction. ${ }^{44}$ The defendants, in the face of this explicit discovery demand, renewed by the objecting shareholders at the settlement hearings, consciously chose not to produce the requested information. ${ }^{45}$ Given the major role played by discovery in the modern adversary process, such conduct should be labelled an extrinsic fraud subjecting the judgment resulting from the court's approval of the settlement in Zenn to collateral attack. Discovery is a right guaranteed to the litigant by statute. ${ }^{46}$ If discovery is to be an effective element of the judicial process, it is absolutely essential that the discoverer be able to trust the good faith of the responses of the opposing party. Otherwise, the discovery process would become a futile exercise, and the judicial process would return to trial by ignorance and surprise. When the person against whom discovery is sought responds that there is no such information or returns certain files and papers, he should be treated as warranting either that the information does not exist or that the information which he has produced is exhaustive. To the extent that the answering party is less than candid in his responses to discovery demands, the discoverer is handicapped in his preparation for trial, and the adversary machinery guaranteed him by statute has been used to prejudice him. As in Callicotte, ${ }^{47}$ the discoverer would be forced to prepare his entire case upon a completely erroneous view of the state of facts. This misinformation would affect the discoverer's ability to contest properly the underlying issues throughout the entire course of litigation. Since the answering party's misconduct in discovery proceedings clearly can be as damaging to the adversary process as bribing an opponent's attorney, it should be denominated an extrinsic fraud. ${ }^{48}$

Although Kirby and similar cases involving misconduct on the part of the defendants in a derivative suit may be disposed of by an intelligent application

44. 333 F.2d at 339.

45. The failure of the $Z$ enn defendants to adduce the critical information was certainly not inadvertent. While the defendants were negotiating with the plaintiffs in $Z$ cmn, Purcell sent Young a December 1950 IDS publication which forecast $300 \%$ increase in IDS carnings for the coming year. Purcell was worried about the schedule's effect on the settlement negotiations - as he observed laconically to Young on an attached note: "This may not be too helpful." 333 F.2d at 339. Apparently Young agreed because the crucial schedule never appeared in the hearings before the referee.

46. See Fro. R. Crv. P. 26-37.

47. Supra, notes $18-21$ and accompanying text.

48. It is essential that perjury at the discovery stage be denominated an extrinsic fraud because the effect of a discovery fraud is to prejudice the individual's entire preparation of the case. The litigant is incapable of functioning as an adversary because of this misinformation. If the person against whom discovery was being sought could respond fraudulently with impunity the entire adversary machinery would prejudiced.

Perjury at the discovery stage should be distinguished from perjury perpetrated from the witness stand. When a witness perjuries himself he is subject to cross-examination. and the trier of fact decides what weight to assign to the witness' testimony on the basis of his credibility. At the discovery stage, whoever, the witness' credibility is not at issue that his responses are candid is assumed. 
of traditional extrinsic fraud doctrine, a novel and more difficult question remains: when may judgments resulting from derivative suit settlements be collaterally attacked for the misconduct of the shareholder plaintiff?

That settlements are normally freely allowed at the behest of the parties reflects our fundamental belief that the plaintiff should have exclusive control over his cause of action, and accordingly be allowed to freely contract for its discontinuance. Further, settlements are encouraged as a means of avoiding the expense and uncertainty connected with litigation while reducing the demands made upon a beleaguered judiciary. The derivative plaintiff, however, unlike the normal litigant, is cast in the role of a representative for his fellow shareholders and may not discontinue or compromise the action at his discretion. ${ }^{49}$ Because of the representative character of the derivative plaintiff, the policy underlying settlement of derivative suits is not that of affording the litigant freedom to contract for discontinuance, but rather that of reducing the expenses, uncertainty and administrative burdens of such litigation. ${ }^{60}$

Since compromise of a class action is res judicata to all members of that class, the judicial system has developed safeguards to insure the protection of absent members of the class. Thus court approval of a proposed compromise of a class action is required. ${ }^{51}$ In many jurisdictions notice must also be sent to all members of the class. ${ }^{52}$ The ultimate purpose of these procedtural safeguards is to assure the absent members of the class that there has been an adequate examination of the underlying cause of action with the court cast in the role of examiner of the fairness of the proposed settlement agreement.t. The court, however, is obviously incapable of conducting a full-scale independent exploration of the cause of action in every case, and must largely rely upon the efforts of the derivative plaintiff for its information. To the extent that the derivative plaintiff has been remiss in his prosecution of the cause of action, the court will be precluded from accurately determining the "fairness" of the settlement figure, and the interests of the absent members of the cliss will not be protected.

49. See note 40 supra.

50. "[A] trial of the case on its merits will undoubtedly be long, and will involve substantial expense ... . . It will cause a diversion of the efforts of its officers from proper attention to the business of the corporation, and may have a possible adverse effect on the good will of the corporation."

Berger v. Dyson, 111 F. Supp. 533, 535-36 (D.R.I. 1953).

51. FED. R. CIV. P. 23(c) ; N.Y. CPLR \& 1005 (c).

52. FEd. R. Crv. P. 23(c); cf. Gerith Realty Corp. v. Normandie Nat'l Securities Corp., 276 N.Y.S. 655 (1933), aff'd, 269 N.Y,S. 1007, aff'd, 266 N.Y. 525, 195 N.E. 183 (1935). Even if notice is not required it will often be given to further assure that the settlement will be res judicata as to subsequent plaintiffs. See Hornstein, New Aspects of Stockholders' Derivative Suits, 47 CoLum. L; Rev, 1, 20 (1947).

53. See generally Moore \& Cohn, Federal Class Actions, 32 In.. L. REv. 307, 321-25 (1937); 3 Moore, Federal Practice $\$ 23.24$ (2d ed. 1955). Cf. Hansberry v. Lee, 311 U.S. 32 (1940). See generally Mclaughlin, Capacity of Plaintiff Stockholder to Tcrminale a Stockholder's Suit, 46 YALE L.J. 421 (1937). 
Failure on the part of the shareholder-plaintiff to prosecute the claim thoroughly is not an infrequent occurrence; one need only recall the omnipresent strike suiter to realize that derivative actions may be litigated less than vigorously. Because of this danger, courts charged with the duty of protecting absent shareholders at settlement should undertake a thorough examination of the record to ascertain whether there hàs been a vigorous prosecution of the cause of action. In exploring the conduct of the derivative plaintiff, the courts should"ask questions such as: was there full use of the discovery machinery; has the plaintiff made full use of other investigatory machinery at his control; was the plaintiff concerned solely with settlement and an immediate contingent fee; who initiated the settlement discussions; how willing was the plaintiff to acquiesce therein ${ }^{54}$ If the court finds no indicia of adversity, the proposed settlement should not be accepted until the court confronts the parties with the lack of adversity and demands from them an express "warranty" to the effect that all the information bearing upon the fairness of the proposed settlement has in fact been adduced.

If, on collateral attack, other shareholders can demonstrate to the second court's satisfaction that the relevant information was not completely adduced, then the other court should vacate the judgment. Under traditional common law doctrine, now incorporated in modern procedural statutes, courts have always had the equitable power to vacate judgments secured through a fraud perpetrated upon the court. 55 The doctrine of fraud upon the court is, in rality, an amorphous rule which has been customarily employed as a tool of the Chancellor. It permits the court to relieve parties from particularly inequitable judgments secured by a party's misconduct which imposes upon the court. ${ }^{\text {to }}$

54. Although there is a general rule that the motives of a derivative plaintiff have no bearing upon his capacity to maintain the action - Wagner Electric Corp. v. Hydraulic Brake Co., 269 Mich. 560, 257 N.W. 884 (1934) - these motives should certainly be relevant in considering whether his representation of absent shareholders has been adequate

55. See FED. R. Crv. P. 60(b).

56. - Characteristic examples of a fraud upon the court are: bribery of the court, Root Refining Co. v. Universal Oil Products Co., 169 F.2d 514 (3d Cir. 1948), cert. denied, sab rom. Universal Oil Products Co. v. William Whitman Co., 335 U.S. 912 (1949); tampering with the jury, Platt v. Threadgill, 80 F. 192 (DD Va. 1897), appeal dismissed, 18 Sup. Ct. 945 (1897).

- See also Hazel-Atlas Glass Co. v. Hartford-Empire Co., 322 U.S. 238 (1944). In Hozel attorneys for the Hartford Company had prepared a concocted article stressing the unique nature of their product in connection with an application for a patent thereon. The patent having been granted, Hartford sued Hazel-Atlas for infringement; the concocted article was introduced in evidence. Mr. Justice Black found this to be a fraud upon the court: "The public welfare demands that the agencies of public justice be not so impotent that they must always be mute and helpless victims of deception and fraud." 322 U.S. at 246. There is not a great difference between -this concocted article and the forged deed in Throckmorton, but obviously the Chancellor's conscience proved more receptive in Hazcl. It has been suggested that the Hasel conduct constituted a "fraud upon the court" beeause it was perpetrated by an attorney - an officer of the court. 7 Moore, Fenerns. Practice 509 (1955). This is not a satisfactory explanation, however, because an attorney vill often be implicated in intrinsic frands; it only provides a convenient means of avoiding entirely the extrinsic-intrinsic fraud rule. Cf. Josserand v. Taylor, 159 F.2d 249 (C.C. Pa. 1946). 
Although the doctrine admittedly has no precise outlines, false responses to a court's demand for assurances as to the completeness of the information adduced before it would unquestionably present an appropriate occasion for application of the doctrine. ${ }^{57}$

Despite their best efforts, courts attempting to determine whether adversity exists will often find it difficult, if not impossible, to ascertain this fact and may therefore be mistaken as to its existence. ${ }^{58}$ If courts are so mistaken, they will neglect to require from the parties a "warranty" that the information in the record is complete. Further, it is unrealistic to assume that all courts will undertake the proposed examination into the adversary nature of the settlement proceedings. In either of these situations, a second court should have the discretion to allow a collateral attack upon the judgment under the equitable doctrine of a fraud upon the court. This doctrine would be appropriate in these circumstances because the derivative plaintiff and the defendant, when they seek court approval of a settlement, should be treated as warranting that the information placed before the court by them represents the restits of a diligent effort on the part of each to contest the relevant issues..$^{50}$ If the derivative plaintiff is not treated as warranting to the court that he has diligently prosecuted the cause of action and, to the extent of his ability, secured all relevant information, the interests of the absent shareholders and the corporation will not be adequately protected. ${ }^{60}$ The vital concern in settlement proceedings ${ }^{01}$ is that absent parties who will be bound should be protected. To this end the law should be structured to secure vigorous prosecution by derivative plaintiffs. ${ }^{62}$

The absent shareholders may have a remedy against the derivative plaintiff who fails to pursue diligently the cause of action; to the extent that the deriva-

57. Cf. Sutter v. Easterly, 354 Mo. 282, 189 S.W.2d 284 (1945). In Sttter the court held that every attorney has an obligation to be honest in his dealings with the court and in the event he is not honest he commits a fraud upon the court. If the attorney has actually responded falsely to a direct question then his dishonesty should be similarly labeled a fraud upon the court because the court is the person to whom the response is directed.

58. A strike suitor who wishes to protect his attorney's fee will be circumspect in maintaining the trappings of adversity.

59. See Sutter v. Easterly, 354 Mo. 282, 189 S.W.2d 284 (1945). If the attorney is, as Sutter holds, an officer of the court bound to conduct himself with absolute integrity, then, to the extent he fails to prosecute diligently his client's claim, he is remiss in his duties to both his client and the court.

60. Protection of absent shareholders and the corporation is the main reason for requiring court approval of derivative suit settlements. See FED. R. Civ. P. 23(c) and N.Y. CPLR $\S 1005(c)$.

61. See note 40 stupra and accompanying text.

62. The mere fact that there have been objecting shareholders who oppose the settlement when the court undertakes to establish its fairness doesn't remedy the plaintiff's failure to prosecute vigorously the derivative action. These objectors are not equipped with the informational resources to provide the missing degree of adversity to safeguard the

corporation's interests. See text at notes 42-43 supra. 
tive plaintiff has a fiduciary duty to prosecute in the best interests of the class he represents, any failure to protect the interests of the corporation and his fellow shareholders would be actionable. ${ }^{63}$ However, saying that the injured corporation and the absent shareholders may proceed against the derivative plaintiff is not enough since his financial resources are generally limited. If the absent shareholders are to be fully protected they must be allowed to vacate the judgment secured as a result of their colleague's neglect and be allowed to proceed against the defendants directly. It is inequitable to allow these defendants to claim the protection of a judgment secured as a result of a settlement with a strike suiter or a non-diligent plaintiff, although they should be allowed to set off the amount paid the original plaintiff in settlement.

Indeed, the suggested rule - that the derivative plaintiff should be treated as warranting to the court that he has completely litigated the relevant issues with due regard for the interests of absent parties - is in accordance with the underlying policy of res judicata and conforms to the purpose of court approval of settlement figures. ${ }^{64}$ Res judicata proceeds from the assumption that the issues underlying the judgment in the previous action were fully litigated and that the parties have had their "day in court." Judicial approval of settlements casts the court in the role of protector of the interests of the absent parties. Where the court neglects to "protect" the interests of absent shareholders by not compensating for the plaintiff's failure to prosecute the claim diligently, the absent shareholders have not had their day in court, and the policy of res judicata should yield to notions of fairness.

63. See Whitten v. Dabney, 171 Cal. 621, 154 Pac 312 (1951); Goodwin v. Castleton, 19 Wash. 2d 748, 144 P.2d 725 (1944). The derivative plaintiff in Whilfen was termed a fiduciary whose duties to his fellow shareholders and to his corporation were held to be akin to a "guardian ad litem."

64. See note $\mathbf{5 3}$ supra. 